\title{
Search for Sustainability in Contemporary Architecture of Iran
}

\author{
Leila Mousavi,*, $^{1, *}$ Mohammadjavad Mahdavinejhad ${ }^{2}$ \\ ${ }^{1}$ Architecture and Energy Department, Kish international Campus, University of Tehran, Iran \\ ${ }^{2}$ Department of Architecture, Faculty of Art and Architecture, Tarbiat Modares University, Tehran, Iran \\ *Corresponding author: leila.mousavi@ut.ac.ir
}

Received August 25, 2013; Revised September 21, 2013; Accepted October 17, 2013

\begin{abstract}
The environmental challenges, the significant effects of architecture, building manufacture technologies and the construction industry have caused the movement towards sustainable architecture to be considered as one of the most important and influential trends in the early years of the $21^{\text {st }}$ century. Sustainable architecture and compliance with environmental features have also been noted in Iran both in theory and practice. However, it seems that in the developing countries, particularly in Iran, the architects' tendency towards the concept of sustainability possesses some features of its own. Therefore, the foremost questions addressed in this study are: 1-what is the main feature of sustainability in Iran's contemporary architecture? And what criteria have been applied for its utilization? 2- What sorts of sustainability- related considerations have been taken into account by the architects and building designers? The methodology adopted to investigate these issues is the conduct of case studies, utilizing the compound strategies. The data collection was performed via a library procedure, whereby thirty samples of Iran's contemporary and post- revolution architecture for which sustainability was considered were selected. The findings of the study reveal that the trend of sustainability in Iran's contemporary architecture mostly manifests itself in attempts to maximize the usage of solar energy, to choose the optimal direction for a building, the light absorption capabilities, proper ventilation based on the specific climate and weather, and the use of plants in the space.
\end{abstract}

Keywords: Iran's contemporary architecture, environment, sustainable architecture

Cite This Article: Leila Mousavi, and Mohammadjavad Mahdavinejhad, "Search for Sustainability in Contemporary Architecture of Iran.” American Journal of Civil Engineering and Architecture 1, no. 6 (2013): 129-142. doi: 10.12691/ajcea-1-6-3.

\section{Introduction}

The application of concepts such as sustainability and sustainable development has opened a new field in architecture which is known as sustainable architecture. It is possible to incorporate sustainable architecture into the important movements of our time since the climate change is the greatest challenge faced by the modern humanity. About 45 percent of the worldwide energy consumption and most of the carbonic gas emission belong to the buildings. Finding a technique for decreasing this energy consumption and using various types of renewable energy sources can inhibit an environmental disaster. Thus, the necessity and urgency of developing the concept of sustainable architecture is quite evident. Each state, according to its own conditions, has sought solutions for this matter. This study aims to undertake series of studies and analyses on some sustainability-oriented buildings in Iran.

\subsection{Description of Issue}

Numerous articles and texts in the architectural literature have addressed sustainability and understanding the related factors. For instance, Simon Dresdner (the theory of sustainability) [1] and Charles Kibert (sustainable construction) [2] have explored these factors in their studies. Some Iranian authors such as Farhad Ahmadi (sustainable architecture) [3] and Seyyed Majid Mofidi (the meaning of sustainable architecture) have discussed and explained the sustainable architecture and its principles [4], while Hamed Kamelnia, Mohammadjavad Mahdavinejad and Darab Diba have conducted a survey on the trends of Iran's contemporary architecture [5]. However, there are only a few studies concerning the combination of Iran's contemporary architecture and sustainability. Hence, this study attempts to investigate the position of sustainability in Iran's contemporary architecture and introduces it as its main objective.

\subsection{Research Questions}

1- What are the features of sustainability in Iran's contemporary architecture and what criteria have been applied for its utilization? 2- What are the sustainabilityoriented considerations followed by the contemporary architects and building designers of Iran?

\subsection{Research Method}

The present study investigates and compares the contemporary works of architecture in Iran through a 
selection of case studies. To this end, the compound methodologies [6] and the library method were respectively employed for acquiring the result and collecting the necessary data. 30 samples of the postrevolution works of the contemporary architecture in Iran were selected and due to the limitation of the article's size, only three were thoroughly discussed and analyzed. For each building, the sustainability parameters taken into account by the designer have been probed. The findings of the thorough study have been classified by the design and the sustainability factors. The sustainability factor itself embraces the three subcategories of economic, social and environmental. Based on the findings of the study, it can be verified that the manifestation of sustainability in Iran's contemporary architecture has mainly been in maximizing the light absorption of the buildings, optimizing the direction, the uttermost use of solar energy and the proper ventilation according to the specific climate and weather conditions, using the local materials accessible in the building site, the proper thermal insulation , the effective means of control and the efficient systems of construction, the use of plants etc.

\section{Research Background}

The sustainable strategy has a long history in architecture and one of its first examples is the way the Neanderthal human, taking the temperature into consideration, learned to use the best spot and direction in the caves he resided in. The other historical example is the study of the three fundamental principles of architecture, the stability, beauty and functionality, by Vitruvius, the architect of the classic age. These principles are still known as the overall features of the sustainable or green architecture [42]; however, the major roots of the natural environment preservation and sustainable architecture movement go back to the $19^{\text {th }}$ century. John Ruskin, William Morris and Richard Letabi are among the pioneers of this movement. In his book "The Seven Lights of Architecture", Ruskin states that it is possible to follow the patterns of natural harmony and order to attain development and evolution. All these pioneers have employed the term "nature" in their eloquent manifests and nowadays, the only proper replacement for this term is "sustainable architecture". Years later, architects such as Frank Lloyd Wright, Peter Aisenman and etc., developed these novel theories.

The flourish of the sustainable architecture movement could not be eliminated by the materialist modernism. Unlike their predecessors, the buildings designed based on the principles of sustainability were flexible and, to some extent, fluid. Richard Rogers claimed that these buildings are like birds, covering themselves with their feathers during the winter and adjusting their metabolism according to the new environmental conditions. Thereby, there is a successful relation between the humans and the nature that stems from this subtle form of design, giving physical realization to the theories of Ruskin, Morris and Letabi [7]. Of the contemporary architects with an impressive record in the sustainable design, the following characters can be named: the Iranian architect, Nader Khalili, the Egyptian architect, Hasan Fathi , the British architect, Norman Foster, Czech architect Ian Kaplici and the Malaysian architect, Kenneth Yiing [42].
In Iran, the researchs conducted by Mohammed Javad Saghafi and Asghar Saed Sameii (The relation between the environment and the nearby materials with energy saving in the building) have revealed that regarding the energy crisis in the world, incompatibility of the materials and the depreciation of the buildings, notably under some certain environmental circumstances, the concept of sustainable design must be further evaluated. Hence, noting the importance of the proper body coverage, the construction of the past buildings in accordance with the climate has been explored. By means of using several tables for illustrating the "probability of incompatibility between the collected or adjacent materials based on the chemical or physical reactions", some proper methods have been pointed out to select a variety of suitable building materials

Finally, plated walls are introduced as the walls which have an "external insulation layer directly installed on them", inhibiting the waste of thermal energy by protecting the whole structure against temperature changes and environmental effects [8]. According to the technical literature of the subject, sustainability is a multidimensional and inter-categorical concept that is overseen by varied theoretical and practical tendencies.

\subsection{Concept of Sustainability}

Today the term "sustainable” is used extensively for universal descriptions in which human and natural systems are continuously able to survive for a long time. [9] This term was initially mentioned in 1986 by the universal committee of environmental development as "facing with present era requirement without disturbing the future resource human for fighting their requirements" and its dimensions and dominance will increase so that it represents a suitable strategy for the world [10]. The verb "sustain" has been used in English language since 1912 and the Oxford dictionary has mentioned the adjective (sustainable) 1400 times and its new form to 1611 times. Nonetheless, it seems that the term "sustainable" had been recently used in history fields. The other meanings and forms of the term "sustainable" have prevailed for many centuries. Yet, it is only in recent decades that sustainability with the current meaning, that is, "whatever that can be continued in the future", has been applied. In Persian the word "stable" means fixed, surviving and perennial- "firm” means permanent- "stanch" means fixed, constant, eternal, survive, firm, stanch, immortal, evergreen- "sustainability" means resistance, mold and stamina - "indelible” means stanch, strength, and surviving, the most prevalent of which are sustain and sustainability [4]. Sustainability means continuity in the action as an activity and creating a stable balance among the effective factors as natural, social and economic factors required for the man.

\subsection{Sustainable Development}

A multitude of definitions have been offered for this phrase, the most prevalent of which is that of Brotedland commission: "sustainable development is a development that secures the current needs of the world without venturing the abilities of the future generation in complying their needs”. The above term has been rewritten and re mentioned. Despite the fact that two 
decades have passed, it is used as an original definition for sustainability [11]. This concept indicates presenting solutions against the traditional pattern of social and economic development so that it could prevent the issues such as destruction of the natural sources, ecosystem, pollution, increasing the population, issuing the injustice and lowering the human life quality [12]. Thus, the important point in sustainable development is that it considers not only the current needs of the world but also the future needs.

\subsection{Sustainable Architecture}

According to Ken Young definition, the sustainable architecture can be considered as the ecologic design. The sustainable architecture can be, in fact, known as a design that has a complete coordination with the Earth's ecological system over its own life cycle. In the sustainable architecture, building materials and the consumed energy are used in a manner to leave the least negative effect on the environment with the least waste of resources [13]. In fact, in the general framework, the sustainable architecture can be phrased as "creating a man-made sustainable environment”. In this definition the sustainable environment is a critical provision for attaining the environmental sustainability and establishing a dynamic balance among the different systems. This provision in the practical viewpoint, is concomitantly achieving sustainability in: 1) ecological system 2) cultural-social system 3) economic system.

Sustainable architecture denotes a process that can be repeated. Sustainability is a concept that is primarily used as a value of a method. The method that confronts the current security needs through a repeatable and stable behavior. Therefore, through this method, the process receives as much attention as the final product. Sustainable architecture truly recognizes that the final product may become dilapidated or need to be replaced over the passage of time. However, it can also recognize the process that can be lasting and stable and which can be renewed or repeated without unnecessary damages to the environment, resources and so forth [14]. Sustainable architecture like other architectural terms has its own special rules and regulations including the three stages of: saving resources, designing for returning to the life cycle, and designing for humans.

\subsection{Current Sustainable Architecture}

In the contemporary architecture, the changes that appear based on ecological and sustainability variables will increasingly have more importance each day. Besides, the concept of sustainability is phrased not only as the physical sustainability of buildings but as preserving an interconnected universality which is the earth and its energy resources. In this regard, prior to wasting or ignoring the available materials and resources, they should be used more efficiently in all aspects. In other words, by applying ecology in building, which emphasizes the integration of building with environmental factors, it seeks to achieve the space and comfort qualities, and suitable form and soul in architecture design [15]. Accomplishing this objective requires having thorough knowledge of the environment and the mechanisms to decrease changes in the environment especially in construction.

\section{Sustainability and Architecture}

\subsection{Sustainability in Buildings}

The purpose of designing sustainable buildings is to decrease the damage on the environment based on energy and using the natural resources including the following rules:

- Decreasing the use of unproducible resources

- Developing the natural environment

- Deleting or decreasing the use of poisonous materials or damaging the environment in construction industry

Some other theorists believe that environmental sustainability in the field of architects works is determined with the following ends:

- Using the energy resources as least as possible

- Using the producible stuffs

- Protecting and supplying the energy and complete recycle without pollution

In the view point of these people sustainable architecture is based on this point that building is a small component of the environment and it should act as a part of ecosystem and put in the life cycle [12]. And the most important point in stating each one is that designing the buildings should be done so that it would protect the environment as much as possible.

\subsection{Climate and Contemporary Architecture of Iran}

Simultaneously developing in the world has also inspired the architecture of buildings of Iranian cities as western skyscrapers and modern buildings. In order to propagate this construction and apply new facilities, the previous principles opposing the environmentally unfavorable conditions have resolved and the new ideas of architecture and urbanization have emerged without considering the natural environments of design; and developed the construction of skyscrapers. Therefore, the construction design of modern cities or reconstruction of old regions was conducted without considering the natural conditions and increased the requirements of unnatural energy consumption. In spite of this condition, however, Iranian famous architects have taken account of the principles of some local architecture in their constructional projects. More recently, using the environmental conditions has received much importance in judgment of architectural competitions, which in turn have inspired the tournaments to design climatic situations. Although building constructions have increased in the country, few projects have made use of these principles, which are limited to huge projects, or the ones conducted by governmental employees and famous counselors. Furthermore, there are a good number of projects that considered stable architecture, however, still many constructions are deprived of such principles and thus, currently designers are trying to use the principles of fixed architecture in their designs, including light getting of structures and its orientation, and considering the regional climate in some residential buildings, villas or large complexes [16].

\section{Objectives and Principles}


The final objective and challenge of stable design, is to find successful solutions that provide users with quantity, quality, as well as physical and mental benefits. To achieve this apparently tough goal, there are many possibilities that inform bioenvironmental problems related to architecture through showing the principles of stable designs.

Some buildings have characteristics that make them among the most stable structures. Structures are therefore classified as stable architecture based on the following principles [17].

\subsection{Energy Conservation}

According to this standard, the structure is to be constructed in a way that minimizes the fossilized fuel requirements. To this end, the following strategies are recommended:

- To maximize the human comforts from absorption of light, air quality, acoustic insulation, controlling the good temperature, desirable humidity control, quality of beneficial supporting and necessary safety provisions, adequate control of human source and effective planning [17]...;

- To design the maximum use of daylight, even in places that are usually restricted;

- To utilize options for natural ventilation within an overall program to regulate the environmental conditions that minimize energy and maximize comforts.

- To frequently use the best reactive methods of solar energy in order to gain warmth and cold, so that the current price is minimized through utilizing the maximum free energies such as daylight, solar warmth, wind, etc.

- Control of temperature changing, good thermal insulation, efficient and appropriate methods of controlling and effective constructional systems and plant use

- To make sure of the simple and complex control methods in building

- To find the methods and situations that could gain electrical energies for design

- To identify the talents that could use the geothermal

- To minimize the water consumption, waste water filtration and re-use

- To minimize the water of raining loss by reducing landscaping with hard materials and considering the proper collection techniques

- To create the pleasant outdoor places by employing appropriate shade for summer.

- To increase the relative humidity necessarily [15]

- To consider the stability of all micro-organisms and green environmental conditions, gathering the rain water and water retrieving, effective retrieval of wastewater and its use [43]

\subsection{Climatic Design}

This principles suggests that buildings should be designed to coordinate with the climate and existence energy sources in construction places and work.

\subsection{Reducing Running Costs}

It is recommended that buildings should be designed in a way that the use of new materials and sources is reduced as much as possible, however, such sources can be used whenever they are found more beneficial.

In line with the abovementioned principles, a set of criteria related to the constructional techniques have been proposed, in which the principles of stable architecture and bioenvironmental problems are observed [18]. These criteria include:

- accommodation of the main materials with nature

- possibility of returning the materials to nature

- energy consumption during the production process and its enforcement

- the wasting degree of materials during transportation and its enforcement

- the quality of using natural resources

- the retrieving ability of materials

So:

- To use the durable materials, long life equipments, simple and reliable environmental controlling systems, achieving the appropriate maintenance and repairs ... that can reduce the costs of building maintenance [17].

- To make optimum use of retrieving and reconstruction materials, avoiding to use all the chemical materials potential of damaging the ozone layer, replacing the materials that wear out gradually and make air pollution, and to value to natural environmental validities.

\subsection{Residents Requirements}

In stable architecture, it is of high importance to meet physical and psychological needs of the residents. The following strategies can be utilized to achieve this goal;

\subsubsection{Simple and Modular Spaces}

These spaces could be reconciled on their own by developing the requirements and easily changing the map and operations inside the constructions. A module is the measurement unit of building that is essential to other measurements and includes micro sizes and is to be used according to the requirements. This measurement system helps the designers to better understand the behavior of the forces applied to the building structure [19]. As was mentioned earlier, the architect is able to create compliant spaces and this will increase the life of building structure [14].

\subsubsection{Optimization}

This can include reducing indoor garden areas, minimizing air-vent installment, maximizing the mixture of the structural elements and installments, reducing installments and engine house, reducing the complexity of spaces and elements, coordinating and harmonizing structures elements, and using an effective structure that does not require a false ceiling in the building [43].

\subsubsection{Effective Planning}

This may include good behavior of consumers in the spaces, making development security, easing the adaption and responding of changing consumer demands and the merger of building structure with installments [43].

\subsection{Coordination with Context}

The structure should be gently placed on the ground and be compatible with the surrounding environment. 


\subsection{Flexibility}

All the principles of stable architecture are to be embedded in a complete process - which leads to a healthy environment. This helps developing the achievement of high quality, safety and welfare standards: 1 - Quality, 2 considering the environment, 3 - considering the future [12].

Table 1. Observance of the type and stability elements (Source: Author)

\begin{tabular}{|c|c|c|c|c|c|}
\hline \multirow{2}{*}{\multicolumn{2}{|c|}{ Design Elements }} & \multicolumn{4}{|c|}{ Stability $^{*}$} \\
\hline & & 1 & 2 & 3 & 4 \\
\hline \multirow{13}{*}{$\begin{array}{c}\text { Form } \\
\text { (volume) }\end{array}$} & Two- shell design & & & & \\
\hline & The design on the pilot & & & & \\
\hline & Creating a central courtyard places & & & & \\
\hline & The impact of body surface area & & & & \\
\hline & Plan form (compressed or stretched) & & & & \\
\hline & Spatial filter & & & & \\
\hline & Windcatcher & & & & \\
\hline & Zamharir (wind tunnel) & & & & \\
\hline & Modular design & & & & \\
\hline & Creating gaps in the body of building & & & & \\
\hline & Green house design & & & & \\
\hline & Thermal storage & & & & \\
\hline & Volume canopy design & & & & \\
\hline \multirow{2}{*}{ orientation } & In the building & & & & \\
\hline & In fenestrations & & & & \\
\hline \multirow{5}{*}{ materials } & Modern and new & & & & \\
\hline & local & & & & \\
\hline & Stabile materials & & & & \\
\hline & Materials with high thermal capacity & & & & \\
\hline & renewable & & & & \\
\hline \multirow{3}{*}{ Light shaft } & $\begin{array}{l}\text { Possibility of light shaft from } \\
\text { windows }\end{array}$ & & & & \\
\hline & Possibility if light shaft from ceiling & & & & \\
\hline & Limitation of light shaft from west & & & & \\
\hline \multirow[t]{2}{*}{ wind } & $\begin{array}{l}\text { Natural ventilation based on thermo } \\
\text { syphon }\end{array}$ & & & & \\
\hline & Creating stream & & & & \\
\hline \multirow{11}{*}{$\begin{array}{c}\text { Application } \\
\text { of solar } \\
\text { elements }\end{array}$} & Absorption cooling system & & & & \\
\hline & EPDM hose & & & & \\
\hline & Hot water tanks & & & & \\
\hline & $\begin{array}{c}\text { Protection technology against } \\
\text { lightening }\end{array}$ & & & & \\
\hline & Electronic eye system & & & & \\
\hline & B.M.S. system & & & & \\
\hline & Solar panels & & & & \\
\hline & Wind turbines & & & & \\
\hline & Louvre & & & & \\
\hline & Hot water networks (stove) & & & & \\
\hline & Passive absorbed devices and tanks & & & & \\
\hline \multirow[t]{2}{*}{ sealing } & Solar lamps & & & & \\
\hline & Walls and roof & & & & \\
\hline \multirow{6}{*}{$\begin{array}{l}\text { Application } \\
\text { of plants }\end{array}$} & Double-glazed glasses windows & & & & \\
\hline & Oxygen station & & & & \\
\hline & Green house design & & & & \\
\hline & Expanding green house space in roof & & & & \\
\hline & Preserve existing trees & & & & \\
\hline & Used as a seasonable shade & & & & \\
\hline site & $\begin{array}{l}\text { The relation of building and the } \\
\text { environment }\end{array}$ & & & & \\
\hline \multirow{7}{*}{$\begin{array}{l}\text { Respecting } \\
\text { to users }\end{array}$} & Acoustic set & & & & \\
\hline & Light set & & & & \\
\hline & Thermal set & & & & \\
\hline & Safety (lightening) & & & & \\
\hline & Flexible design & & & & \\
\hline & Good spatial relation & & & & \\
\hline & Suitable view & & & & \\
\hline
\end{tabular}

\section{Case Study Analysis}

\subsection{Selection of Case Studies}

In this section the concept of stability and its realization in Iranian contemporary architecture samples is being dealt with. To this end, the type and stability of each studied buildings is illustrated on the related chart. Then a comparison is made between the results. Given the Iranian contemporary architecture, the type of stability and its factors, as were discussed in the previous section have also been regulated on descriptive- analytic observations (Table 1). To analyze the concept of stability in Iran's contemporary architecture, the population statistics are collected including all the works of Iranian contemporary architecture dating from the Islamic Revolution of Iran as mentioned in the specialized Journal. Among all the works, a number of 30 structures were chosen for the purpose of observations. In the present paper, a detailed account of three of the works is being represented. Yet the final conclusions are related to the analyses of all the 30 works of Iranian contemporary architecture.

Table2. shows the stability's different type in Table 1

\begin{tabular}{|c|c|c|c|}
\hline \multicolumn{2}{|c|}{ Stability } \\
\hline 1 & 2 & 3 & 4 \\
\hline \multirow{2}{*}{ Economical } & \multirow{2}{*}{ Social } & \multicolumn{2}{|c|}{ Environmental } \\
\cline { 3 - 4 } & & Natural Warmth & Natural Cold \\
\hline
\end{tabular}

\subsection{Introduction And Analysis of Selection Building:}

5.2.1. Solar Building, University of Science and Technology (Designer: Bijan Rafii)

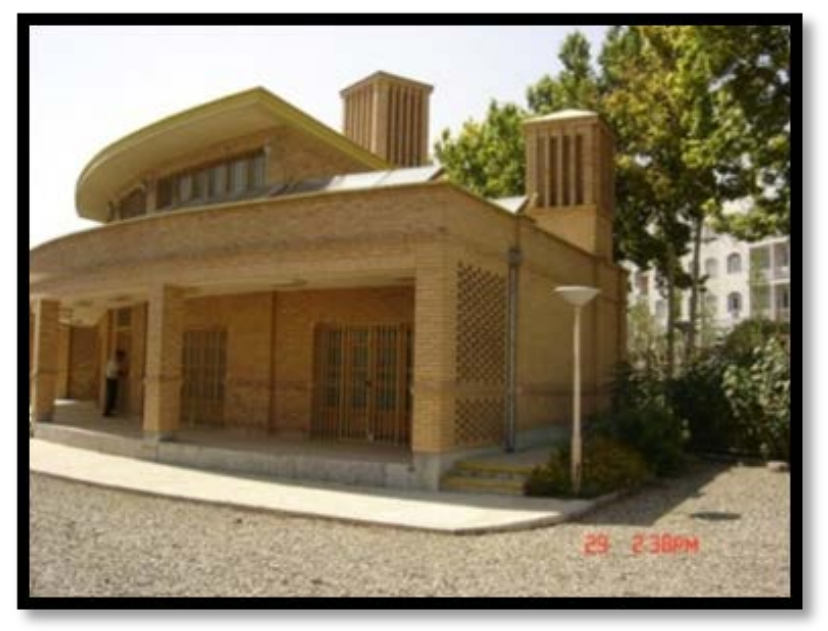

Figure 1. Solar Construction in university of Science and Technology

This solar building uses the natural renewable sources of energy such as the sun light and the wind to provide heat for the winter and uses the basement coolness in order to provide cool air in summer and the deficiency of adequate warmth is overcome by the provision of two fireplaces without furnaces (Figure 1).

- Winter function:

To reduce the need for fossil fuels in buildings, thermal insulation is considered as an effective solution The general belief is that a good solar building is the one having been properly insulated. In order for this feature to 
be observed, the following specifications were predicted as for the building operation in winter:

1. Exterior walls of the building have been built with two $20 \mathrm{~cm}$ layers of brick wall with a10 cm layer of dry and static air. To prevent air movement between the walls, in a wooden board was placed at every $60-70 \mathrm{~cm}$.

2. Wooden doors and double glazed windows are used

3. To predict two entrance to prevent the cold air.

4. Facade facing the sun is open and exposure to sunlight and northern facade is closed and smaller. Eastern and western facades are closed too, as shown in Figure 2.

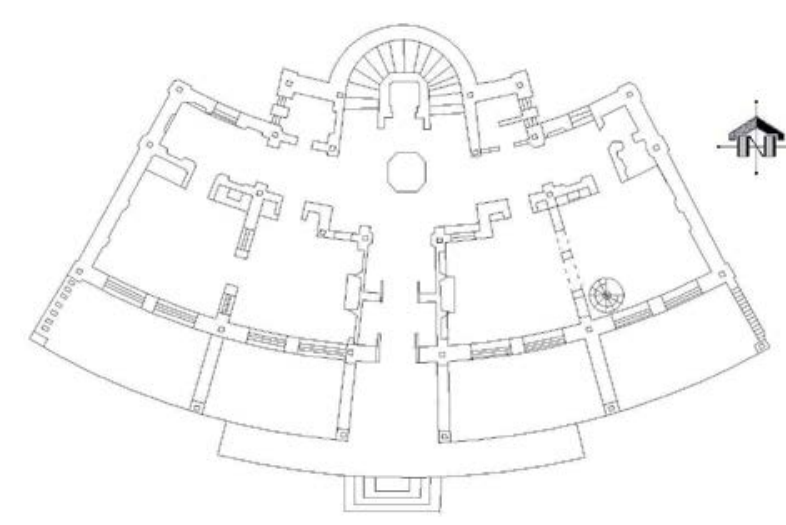

Figure 2. The solar building plan in university of Science and Technology

5. The northern corridor acts as an insulator layer between the outside air and the air chamber works. In fact, the northern corridor is the second shield wall after insulation of the North wall in the winter. The northern walls of the rooms are the third of the shield.

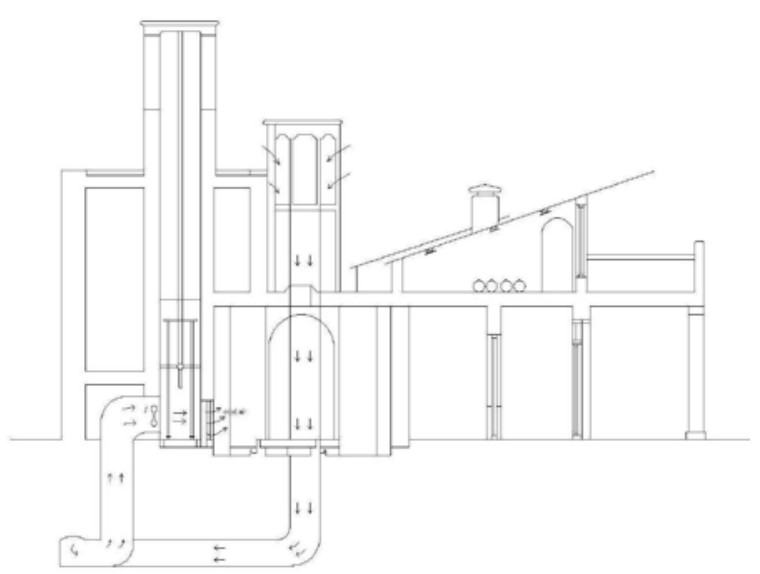

Figure 3. underground channels of Zamharir and Windcatcher

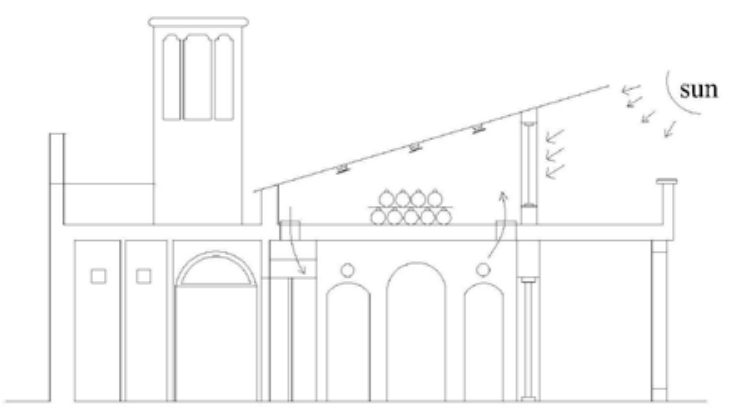

Figure 4. the heat transfer procedure from the stove

6. There is a room with many pots in the roof that is full of water and serves to maintain the warm water. Two electrical chimneys send hot air into the room and a thermostat sets the air flow day and night. This room also plays an important role in the operation of un-conductor air layers between the outside and inside of the room as shown in Figure 4.

Table 3. summarizes the type and stablity factors for the solar building of Iran University of Science and Technology (Source: Author)

\begin{tabular}{|c|c|c|c|c|c|}
\hline & \multirow{2}{*}{ Design Elements } & & \\
\hline & & 1 & 2 & 3 & 4 \\
\hline \multirow{13}{*}{$\begin{array}{l}\text { Form } \\
\text { (volume) }\end{array}$} & Two- shell design & & & & \\
\hline & The design on the pilot & & & & \\
\hline & Creating a central courtyard places & & & & \\
\hline & The impact of body surface area & & & & \\
\hline & Plan form (compressed or stretched) & & & & \\
\hline & Spatial filter & & & & \\
\hline & Windcatcher & & & - & - \\
\hline & Zamharir (wind tunnel) & & & & $\bullet$ \\
\hline & Modular design & & & & \\
\hline & Creating gaps in the body of building & & & & \\
\hline & Green house design & & & & \\
\hline & Thermal storage & & & & \\
\hline & Volume canopy design & & & & - \\
\hline \multirow{2}{*}{ orientation } & In the building & & & $\bullet$ & $\bullet$ \\
\hline & In fenestrations & & & & \\
\hline \multirow{5}{*}{ materials } & Modern and new & & & & \\
\hline & local & - & & & \\
\hline & $\begin{array}{l}\text { Stabile materials } \\
\end{array}$ & & & & \\
\hline & Materials with high thermal capacity & & & $\bullet$ & - \\
\hline & renewable & & & & \\
\hline \multirow{3}{*}{ Light shaft } & $\begin{array}{c}\text { Possibility of light shaft from } \\
\text { windows }\end{array}$ & & & - & \\
\hline & Possibility if light shaft from ceiling & & & & \\
\hline & Limitation of light shaft from west & & & & - \\
\hline \multirow[t]{2}{*}{ Wind } & $\begin{array}{c}\text { Natural ventilation based on thermo } \\
\text { syphon }\end{array}$ & & & & \\
\hline & Creating stream & & & & \\
\hline \multirow{11}{*}{$\begin{array}{l}\text { Application } \\
\text { of solar } \\
\text { elements }\end{array}$} & Absorption cooling system & $\bullet$ & & & \\
\hline & EPDM hose & & & & \\
\hline & Hot water tanks & - & & & \\
\hline & $\begin{array}{c}\text { Protection technology against } \\
\text { lightening }\end{array}$ & & & & \\
\hline & Electronic eye system & & & & \\
\hline & B.M.S. system & & & & \\
\hline & Solar panels & - & & & \\
\hline & Wind turbines & & & & \\
\hline & Louvre & & & & \\
\hline & Hot water networks (stove) & & & $\bullet$ & \\
\hline & Passive absorbed devices and tanks & & & - & \\
\hline \multirow[t]{2}{*}{ sealing } & Solar lamps & & & & \\
\hline & Walls and roof & $\bullet$ & & - & $\bullet$ \\
\hline \multirow{6}{*}{$\begin{array}{l}\text { Applications } \\
\text { of plants }\end{array}$} & Double-glazed glasses windows & & & & \\
\hline & Oxygen station & - & & - & - \\
\hline & $\begin{array}{l}\text { Green house design } \\
\end{array}$ & & & & \\
\hline & Expanding green house space in roof & & & & \\
\hline & Preserve existing trees & & & & \\
\hline & Used as a seasonable shade & & & & \\
\hline site & $\begin{array}{c}\text { The relation of building and the } \\
\text { environment }\end{array}$ & & & & \\
\hline \multirow{7}{*}{$\begin{array}{l}\text { Respecting } \\
\text { to users }\end{array}$} & Acoustic set & & & & \\
\hline & Light set & & & & \\
\hline & Thermal set & & & & \\
\hline & Safety (lightening) & & & & \\
\hline & Flexible design & & & & \\
\hline & Good spatial relation & & & & \\
\hline & Suitable view & & & & \\
\hline
\end{tabular}

- Summer function:

1. Part 1, 2 and 3 that were described in the last section are also used here to keep inside the building cool in summer. 
2. The underground cold air enters the building through a chimney and two underground windcatcher and channels called "Zamharir". When this windcatcher can cool the building, it does not use the Zamharir. In hot days, however, the Zamharir is of much help in keeping the inside sufficiently cold, as shown in Figure 3.

3. Eastern and western facades prevent the entrance of sunlight into the building in summer without windows and doors.

4. The porch prevents the sunlight from entering the room during the summer. Yet in the winter, the sunlight can easily come into the building [18] (Table 3).

The projects enjoys a number of positive features, including the easy proposed solutions independent of the complex construction techniques, efficient climate design based on materials, availability of construction equipment and methods, comprehensibility to the public as well as its educational aspects that have been pervasively used as practice patterns widespread (even in a village). Potential disadvantages of the building include a hard designing emphasis on building construction methods and masonry materials, designing of the wall (in the heat aspect) and utilizing most of human sources in architecture and structures, direct and inflexible designing of the entire interior of the building, the limited results of natural windcatcher due to the limited wind at the site, nonplacement of optimum orientation and regulating the angle of placement related to the North - South axis in terms of climatic designing [21].

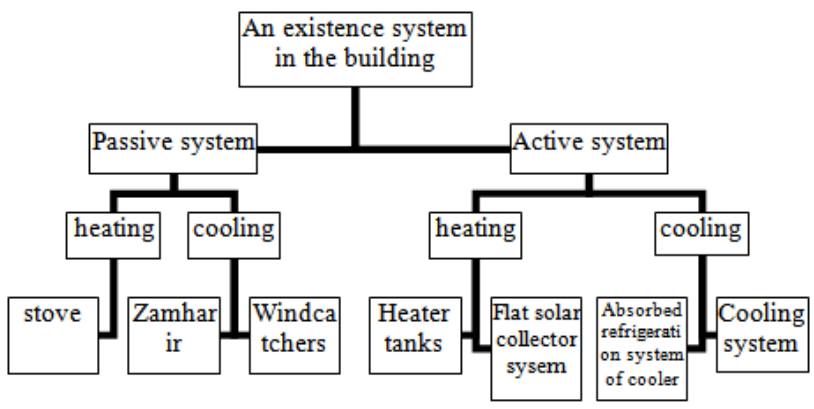

Diagram 1. Classification of solar systems in buildings

\subsubsection{Supreme Audit Court Of Country (Designer: Mohammad Taghi Rezayi Hariri)}

This project is the first building structure experience in Iran with two surfaces which has 18 floors and it is constructed on new methods based on the use of solar energy to heat and cool the buildings, and has been designed to save fossil fuels. (Figure 5) the plan of bulding is a 30x30 square meters (five structural openings in $6 \mathrm{~m}$ ) and is extended to North and South ,if turned to south-east side. (Figure 6) A $75 \mathrm{~cm}$ module base was chosen to design the building based on the dimensions of the furniture:

- The plan and axes of structure with distances of 6 meters $(8 \times 0.75=6)$.

- The cross-sectional distances and height of floors equivalence to $3.75 \mathrm{~m}(5 \times 0.75=5)$ (Figure 7).

The factors that formed the building include $75 \mathrm{~cm}$ glasses or $75 \mathrm{~cm}$ free spaces that are designed with the purpose of climatic, acoustic and installment operations. (Figure 8) the outer glass layer and inner one is made of light wall (commercial called kanaf) with a very low thermal conductivity coefficient by thermal insulation and limited double-glazed windows. The space between the wall and the window is naturally ventilated using the thermosifon phenomenon with no energy requirements.

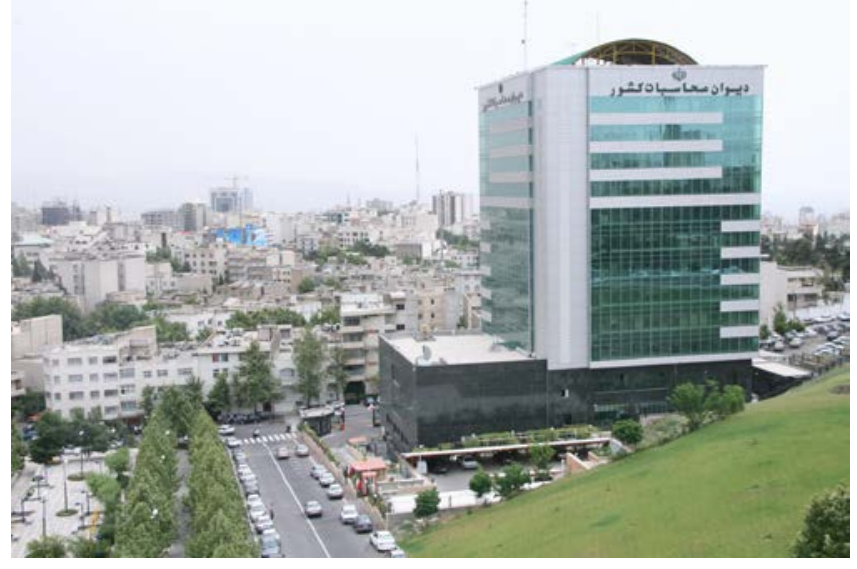

Figure 5. Supreme Audit Court Of Country

The outer layer of the building is fixed and fixed and could not be opened, but it has formed a space for ventilation in each two floor that has a window with $3 \mathrm{~cm}$ safety space beyond. These spaces are formed with a height of two floors, which one is open and the other is closed, as a result, air flows between each one of two floors. Double layer construction of climatic operation in the winter and summer is described below [21].

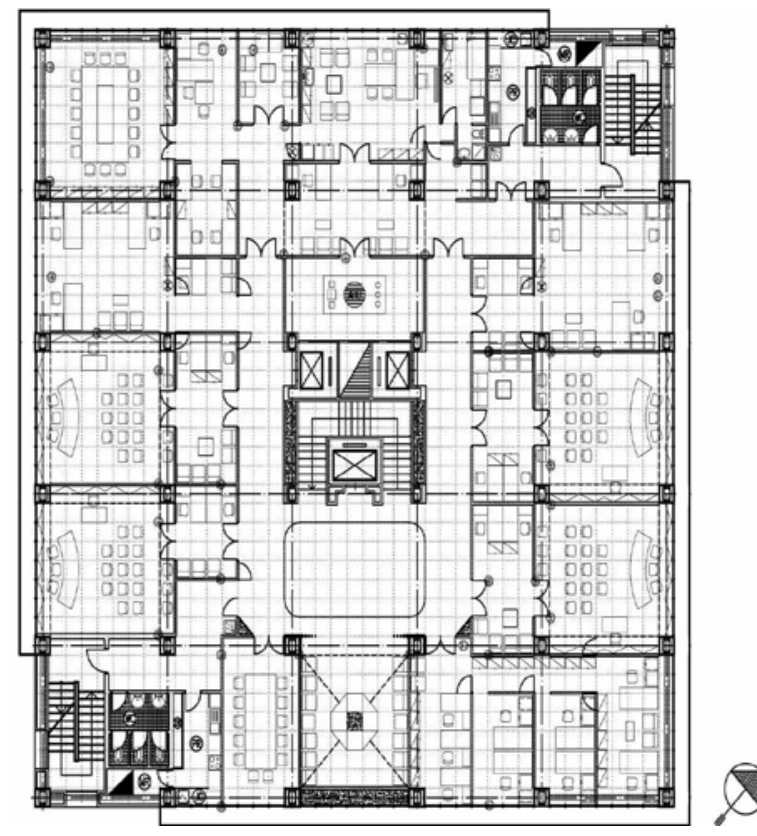

Figure 6. the modular design of plan

- Winter function

In winter, the main problem is the wind that causes the loss of the heat in the building. Due to the existence of the outer glass layer, the wind does not get into the interior layer. Therefore, the main body of the building will be protected from the wind. Meanwhile, although the cold air enters the building through the seams, due to heat radiation of the inner wall, both warm and cold air masses clash, and thus they go up and run away. In other words, the cold air does not clash with the main wall of the building. which in turn reduces the energy consumption for heating buildings. Moreover, with the help of the sun 
radiation, it helps naturally creating thermal comfort in buildings[21].

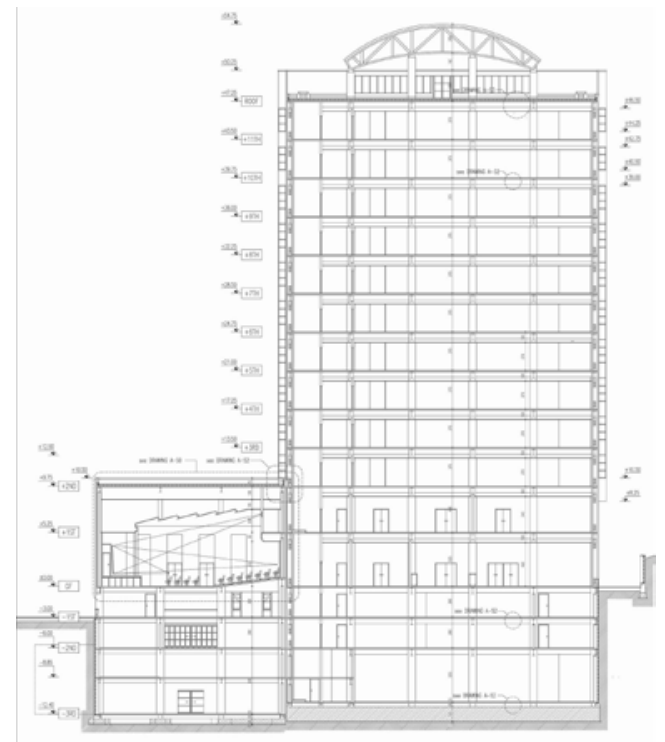

Figure 7. The modular section shows the function of two shell envelope design

\section{- Summer function}

The sun's rays pass through the glass layer and clash with the inner layer, then raise the temperature of the inner wall in relation to the environment (about 22-38 degrees temperature in Tehran). Hence, the air between two layers begins to get warm and due to physics' laws it goes up and pass away from the vertical space beyond glasses and aluminum blinds (window shade). This air is cooler than the layers and passes through inside the building. As a result, the inner layer is not so hot to overload the mechanical cooling system. In addition, due to the use of 10 -cm insulation on the inside of the layer and thermal resistance, radiation will not enter the building. Unfortunately the west side of the building becomes hot and its temperature rises above the comfort level. This is caused by not installing the horizontal blinds predicted to exist between the layers in the west and east side of the building. Unfortunately, the blinds were omitted by the task manager.

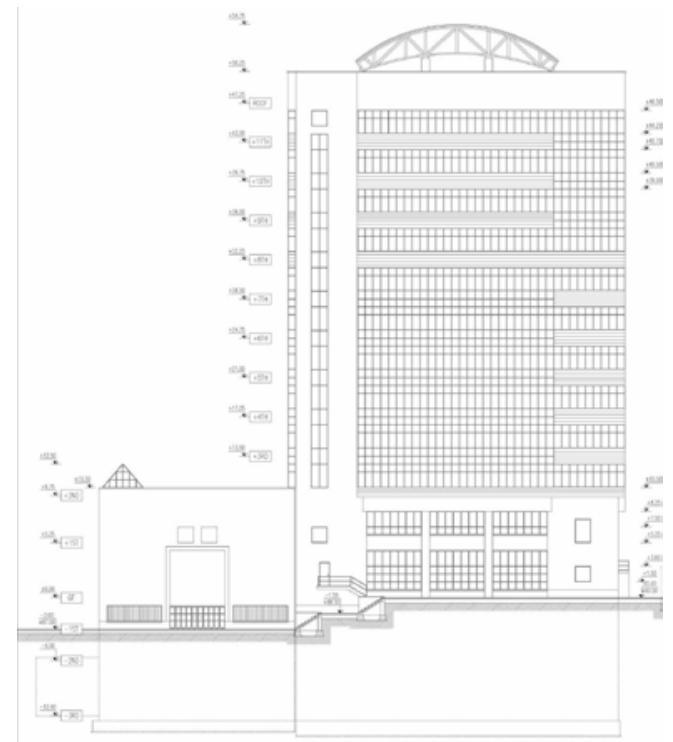

Figure 8. The building elevation shows the modular concept
The key issue in order to maintain the building stability is to create a flexible, reusable and convertible space for the future applications. This feature has obtained by separating the stairs, the elevator and the ducts from the main parts of building. Another specification of this building is observing the stable architecture principles and respecting the costumers by acoustic, thermal and light setting and building security by observing other techniques and standards.

Table 4. represents the type and stability factors in the Audit office of country (Source: Author)

\begin{tabular}{|c|c|c|c|c|c|}
\hline & \multirow{2}{*}{ Design Elements } & \multicolumn{4}{|c|}{ Stability $^{*}$} \\
\hline & & 1 & 2 & 3 & 4 \\
\hline \multirow{13}{*}{$\begin{array}{c}\text { Form } \\
\text { (volume) }\end{array}$} & Two- shell design & & & $\bullet$ & $\bullet$ \\
\hline & The design on the pilot & & & & \\
\hline & Creating a central courtyard places & & & & \\
\hline & The impact of body surface area & & & & \\
\hline & Plan form (compressed or stretched) & & & $\bullet$ & \\
\hline & Spatial filter & & & & \\
\hline & Windcatcher & & & & \\
\hline & Zamharir (wind tunnel) & & & & \\
\hline & Modular design & & & & \\
\hline & Creating gaps in the body of building & & & & \\
\hline & Green house design & $\bullet$ & & & \\
\hline & Thermal storage & & & & \\
\hline & Volume canopy design & & & & \\
\hline \multirow{2}{*}{ orientation } & In the building & & & $\bullet$ & \\
\hline & In fenestrations & & & & \\
\hline \multirow{5}{*}{ materials } & Modern and new & & & & \\
\hline & local & & & & \\
\hline & Stabile materials & & & & \\
\hline & Materials with high thermal capacity & & & & \\
\hline & renewable & & & & \\
\hline \multirow{3}{*}{ Light shaft } & $\begin{array}{c}\text { Possibility of light shaft from } \\
\text { windows }\end{array}$ & & & $\bullet$ & \\
\hline & Possibility if light shaft from ceiling & & & & \\
\hline & Limitation of light shaft from west & & & & \\
\hline \multirow[t]{2}{*}{ wind } & $\begin{array}{c}\text { Natural ventilation based on thermo } \\
\text { syphon }\end{array}$ & & & & $\bullet$ \\
\hline & Creating stream & & & & \\
\hline \multirow{11}{*}{$\begin{array}{c}\text { Application } \\
\text { of solar } \\
\text { elements }\end{array}$} & Absorption cooling system & & & & \\
\hline & EPDM hose & & & & \\
\hline & Hot water tanks & & & & \\
\hline & $\begin{array}{c}\text { Protection technology against } \\
\text { lightening }\end{array}$ & & & & \\
\hline & Electronic eye system & & & & \\
\hline & B.M.S. system & & & & \\
\hline & Solar panels & & & & \\
\hline & Wind turbines & & & & \\
\hline & Louvre & & & & \\
\hline & Hot water networks (stove) & & & & \\
\hline & Passive absorbed devices and tanks & & & & \\
\hline \multirow[t]{2}{*}{ sealing } & Solar lamps & & & & \\
\hline & Walls and roof & & & $\bullet$ & $\bullet$ \\
\hline \multirow{6}{*}{$\begin{array}{l}\text { Applications } \\
\text { of plants }\end{array}$} & Double-glazed glasses windows & & & $\bullet$ & $\bullet$ \\
\hline & Oxygen station & & & & \\
\hline & Green house design & & & & \\
\hline & Expanding green house space in roof & & & & \\
\hline & Preserve existing trees & & & & \\
\hline & Used as a seasonable shade & & & & \\
\hline site & $\begin{array}{c}\text { The relation of building and the } \\
\text { environment }\end{array}$ & & & & \\
\hline \multirow{7}{*}{$\begin{array}{l}\text { Respecting } \\
\text { to users }\end{array}$} & Acoustic set & & $\bullet$ & & \\
\hline & Light set & $\bullet$ & $\bullet$ & & \\
\hline & Thermal set & $\bullet$ & $\bullet$ & $\bullet$ & $\bullet$ \\
\hline & Safety (lightening) & & $\bullet$ & & \\
\hline & Flexible design & & $\bullet$ & & \\
\hline & Good spatial relation & & & & \\
\hline & Suitable view & & & & \\
\hline
\end{tabular}

The glass layer of this building is made of a kind called security glasses that functions better than laminated glass in the case of an earthquake. Laminated glass panel is 
removed at the time of the earthquake and falls on the ground. In contrast, security glass gets a powder-shape which is more secure for the surrounding space in terms of stability [21] (Table 4).

\subsubsection{Iranian Solar House}

Table 5. illustrates the type and stability factors of Iranian solar house (Source: Author)

\begin{tabular}{|c|c|c|c|c|c|}
\hline \multirow{2}{*}{\multicolumn{2}{|c|}{ Design Elements }} & \multicolumn{4}{|c|}{ Stability $^{*}$} \\
\hline & & 1 & 2 & 3 & 4 \\
\hline \multirow{13}{*}{$\begin{array}{c}\text { Form } \\
\text { (volume) }\end{array}$} & Two- shell design & & & & \\
\hline & The design on the pilot & & & & \\
\hline & Creating a central courtyard places & & & & \\
\hline & The impact of body surface area & & & & \\
\hline & Plan form (compressed or stretched) & & & & \\
\hline & Spatial filter & & & & \\
\hline & Windcatcher & & & & \\
\hline & Zamharir (wind tunnel) & & & & \\
\hline & Modular design & & & & \\
\hline & Creating gaps in the body of building & & & & \\
\hline & Green house design & & & & \\
\hline & Thermal storage & & & & \\
\hline & Volume canopy design & & & & \\
\hline \multirow{2}{*}{ orientation } & In the building & & & & \\
\hline & In fenestrations & & & & \\
\hline \multirow{5}{*}{ materials } & Modern and new & & & & \\
\hline & local & & & & \\
\hline & Stabile materials & & & & \\
\hline & Materials with high thermal capacity & & & & \\
\hline & $\begin{array}{ll}\text { renewable } \\
\end{array}$ & & & & \\
\hline \multirow{3}{*}{ Light shaft } & $\begin{array}{l}\text { Possibility of light shaft from } \\
\text { windows }\end{array}$ & & & $\bullet$ & \\
\hline & Possibility if light shaft from ceiling & & & & \\
\hline & Limitation of light shaft from west & & & & \\
\hline \multirow[t]{2}{*}{ wind } & $\begin{array}{c}\text { Natural ventilation based on thermo } \\
\text { syphon }\end{array}$ & & & & \\
\hline & Creating stream & & & & \\
\hline \multirow{11}{*}{$\begin{array}{l}\text { Application } \\
\text { of solar } \\
\text { elements }\end{array}$} & Absorption cooling system & & & & \\
\hline & EPDM hose & - & & & \\
\hline & Hot water tanks & - & & - & \\
\hline & $\begin{array}{l}\text { Protection technology against } \\
\text { lightening }\end{array}$ & & & & \\
\hline & Electronic eye system & & & & \\
\hline & B.M.S. system & & & & \\
\hline & Solar panels & & & & \\
\hline & Wind turbines & & & & \\
\hline & Louvre & & & & \\
\hline & Hot water networks (stove) & & & & \\
\hline & Passive absorbed devices and tanks & & & & \\
\hline \multirow{2}{*}{ sealing } & Solar lamps & - & & & \\
\hline & Walls and roof & & & & \\
\hline \multirow{6}{*}{$\begin{array}{l}\text { Applications } \\
\text { of plants }\end{array}$} & Double-glazed glasses windows & & & - & $\bullet$ \\
\hline & Oxygen station & & & & \\
\hline & Green house design & & - & & \\
\hline & Expanding green house space in roof & & & & \\
\hline & Preserve existing trees & & & & \\
\hline & Used as a seasonable shade & & & & \\
\hline site & $\begin{array}{c}\text { The relation of building and the } \\
\text { environment }\end{array}$ & & & & \\
\hline \multirow{7}{*}{$\begin{array}{l}\text { Respecting } \\
\text { to users }\end{array}$} & Acoustic set & & - & & \\
\hline & Light set & & $\bullet$ & & \\
\hline & Thermal set & & - & & \\
\hline & Safety (lightening) & & & & \\
\hline & Flexible design & & & & \\
\hline & Good spatial relation & & & & \\
\hline & Suitable view & & & & \\
\hline
\end{tabular}

The factors such as using the local light, heating and cooling the building and costumer behavior are important components in building designing. All the light, heating and cooling energies are provided through solar energy of this structure. The main objective of this project is to reduce the energy, using daylight and to receive the maximum solar light in big windows. The seven-watt LED lamps powered by electrical solar batteries provide the light required for studying (Figure 11), and 12-watt lamps maintain the whole room with enough light and it is how the shortage of building light is compensated. Since in this building two layer windows were used to receive the solar light, UV radiation enters the building which heats the space. Besides, a filter is also installed on this window to prevent the entrance of $99.9 \%$ of the UV radiation into the building. In this project instead of using $4 \mathrm{~cm}$ insulations including benzene that is harmful to the human health, Nano-insulation is utilized (which is believed to be harmless to human health) to heat the space in cold weather. The required hot water is maintained using solar water heaters with the capacity of maintaining the 200 liters of warm water for the period of 5 hours as shown in Figure 9\& Figure 10 (Table 5).

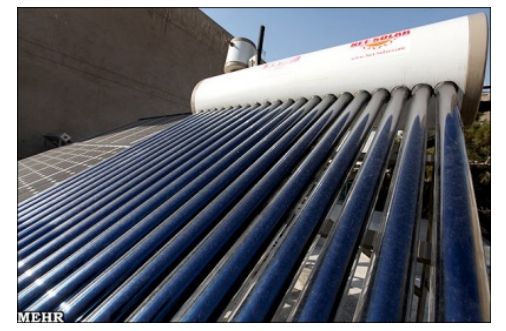

Figure 9. the solar heater provides hot water in winter with temperatures of 60 degrees

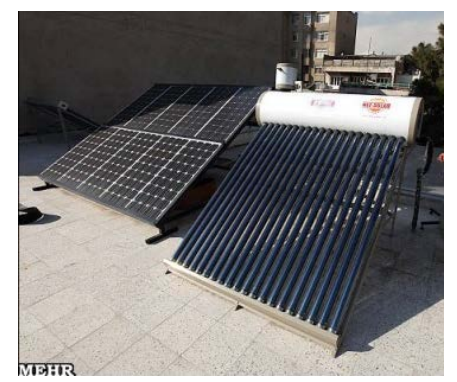

Figure 10. the solar heater provides hot water in winter with temperatures of 60 degrees

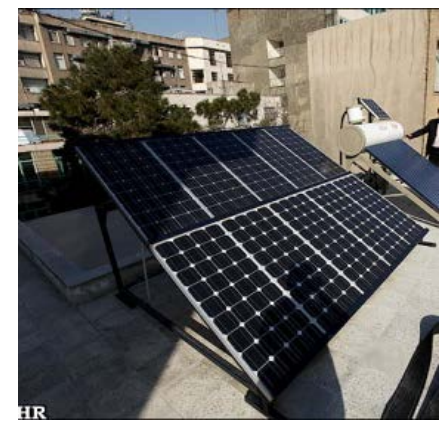

Figure 11. solar photovoltaic system

The sun light that clashes with the two layer pipes and stores hot water in 200 liter high source. In this building, plants have been used to supply the needed moisture, and also two kinds of "Rose" with the ivy called "Aminoldoleh" are cultivated. The plants produce moisture, which acts like water coolers in the environment.

When a place's oxygen density is high, people don't feel tired and this oxygen is generally created by plants. In this building a heating system has been employed for outdoor pools to heat the water with a hose as shown in Figure 12. 
This hose called EPDM and can provide hot water for swimming pools and water parks with Using solar energy.

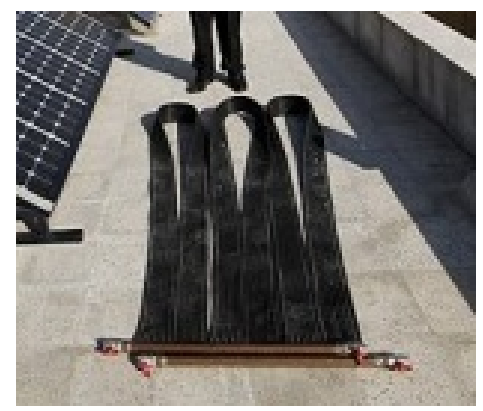

Figure 12. EPDM hose used for heating swimming pools and water parks

\section{Discussion}

Given the 30 completed buildings chosen for the purpose of analyses, the following observations were made:

In 56 percent of the buildings, stability has been considered in a manner that the details on the form of the buildings have been different according to the varied climates [22]. This design of the buildings under study is used as follows:

- Using the two-shell design for building (including inner shell and the outer shell of the building)

- The pilot design (related to the hot and humid climate so that the air circulates in the whole body of the building)

- Creating a central courtyard (to increase the lightshaft views) [23].

- The impact of body surface area (to increase or decrease the continent shots facing the wind according to the climate)

- Plan form (which with respect to different climates causes the compressed or stretched volumes)

- Space filtering (is used in spaces that require heating and cooling to prevent the loss of heat or cold)

- Windcatcher (for an inactive cooling system)

- Zamharir (for the flow of the underground cool air to the building through the electrical chimney)

- Modular design (in order to ensure the flexibility of the building)

- Making a hole in the building (to maximize the use of wind in hot and humid climates)

- Green house design (to get maximum sunlight in the South view)

- Heat store (using pool water with high thermal capacity to evaporate hot air softly through cooling in summer and moisturize dry air in winter)

- Designing the volume canopy (to control the sunlight entering the space)

It was also revealed from the analyses that in $20 \%$ of the cases, the building orientation has been considered as the stability factor, and this orientation has been mostly used in direction of building itself and in a few cases is devoted to changing the orientation of fenestrations. 26\% of the buildings have been considered to achieve stability of the chosen materials. In some buildings, modern materials were utilized including the glass brick to transfer the middle space and also major glasses to control the entrance of the light into the building and sometimes local and regional materials were used according to type of architecture. There were also cases where high thermal capacity materials were selected to construct buildings in which many bricks have been used and are finally capable of being recycled in the Eco-cycle, and usually wood is regarded as one of these materials.

Some of the important points which are often disregarded by the designers include the selection of materials, heating of the building, using the plants, coordinating the building with environment as well as solar elements. Some of these elements were incorporated in the samples and models in a way that limited the designers and this can be related to the current unfamiliarity of these systems in the field of energy which leads in not using the systems. In some projects new systems have been proposed, however, they all have been discarded by the employees or during the operation due to financial difficulties or for non-capability of human sources. Therefore, in designing new systems, it is necessary to keep an eye open for the operation of the project and its primary costs.

Given the light getting of the buildings, part of the findings indicated that $73 \%$ of the buildings have considered the stability phenomenon which signifies the highest attention among the other stability factors. The capability of absorbing the light from windows in a way that the maximum light is transfered to the inner space or by using skylights the maximum comfort of space.light and brightness is produced for the space is what mostly taken into consideration. And designers have tried to limit the unwanted lights and achieve the maximum comfort of space. Among these buildings, 30\% used the wind flow in some parts to ventilate the space based on thermosyfon phenomenon [24], while other parts make use of natural cooling. The solar elements have been used in $16 \%$ buildings in the following areas:

- Water coolong system (that is one part of active cooling system)

- EPDM Hose (can provide water for swimming pools and water parks with the use of solar energy)

Hot water tanks (one of the active heating systems)

- Protection Technology for electric storm

- Electronic Eye Systems

- Solar panels and wind turbines (to provide the energy in the building)

- Louvre (Used as Shading)

- Heater network (stove) (tanks full of water or a liquid to store the heat of the water)

- Solar lamp (LED lamps that use solar power batteries)

It seems that most of the solar elements that are introduced in the items are very limited and using of them is intangible for building. this fact can be because of unfamilarity of architectures with modern systems in energy part that will cause lack of interest in them for using such modern systems. in some of projects , modern systems have been designed but because of limitation in finacial capacities or Insufficiency of executive group , in the executive level they have been bypassed. so paying attention to existance of Efficient force, for executing the project and devotion of enough primary cost is very neccesary. 
Table 6. Considering the stability factors in the samples (1-15) (source: author)

\begin{tabular}{|c|c|c|c|c|c|c|c|c|c|c|c|c|c|c|c|c|}
\hline \\
\hline & Stability factors in design & 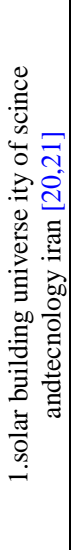 & 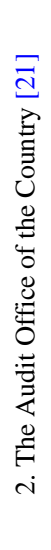 & 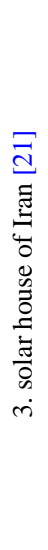 & 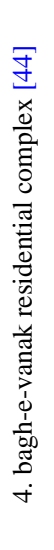 & 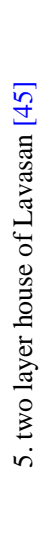 & 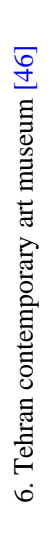 & 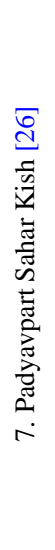 & 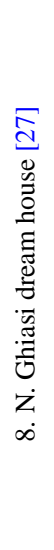 & 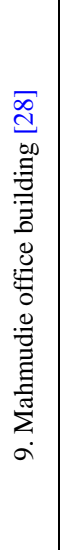 & 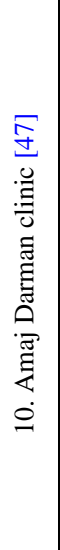 & 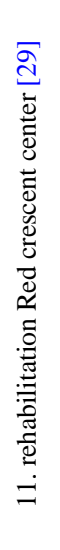 & 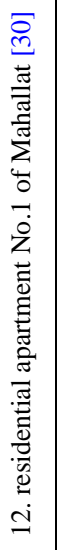 & 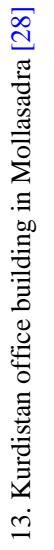 & 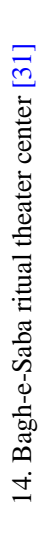 & 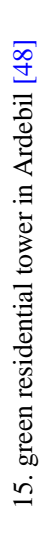 \\
\hline \multirow{13}{*}{$\begin{array}{c}\text { Form } \\
\text { (volume) }\end{array}$} & Two- shell design & & $\bullet$ & & & - & & & & & & & & & & \\
\hline & The design on the pilot & & & & & & & - & & & & & & & & \\
\hline & Creating a central courtyard places & & & & - & & - & & & & & & & & & \\
\hline & The impact of body surface area & & & & & & & & & & & & & & & \\
\hline & Plan form (compressed or stretched) & & - & & & & & - & & & & - & & & & \\
\hline & $\begin{array}{c}\text { Spatial filter } \\
\end{array}$ & - & & & & & & & & & & & & & & \\
\hline & Windcatcher & - & & & & & - & & & & & & & & - & \\
\hline & Zamharir (wind tunnel) & - & & & & & & & & & & & & & & \\
\hline & Modular design & & - & & & & & & & & & & & & & \\
\hline & Creating gaps in the body of building & & & & & & & - & & & & & & & & \\
\hline & Green house design & & & & & & & & & & & & & & - & \\
\hline & Thermal storage & & & & & & & & & & & & & & & \\
\hline & Volume canopy design & - & & & & & & - & & & & - & & - & - & \\
\hline \multirow{2}{*}{ orientation } & In the building & $\bullet$ & - & & & & & - & & & & - & & & & \\
\hline & In fenestrations & & & & & & & & & & & & - & & & \\
\hline \multirow{5}{*}{ materials } & Modern and new & & & & & & & & & & & & & & & \\
\hline & local & - & & & & & & & - & - & - & - & - & & & \\
\hline & Stabile materials & & & & & & & & & & & - & & & & \\
\hline & Materials with high thermal capacity & - & & & & & & & & & & - & & & & \\
\hline & renewable & & & & & & & & & & & - & - & & - & \\
\hline \multirow{3}{*}{ Light shaft } & Possibility of light shaft from windows & $\bullet$ & - & - & - & - & - & & & - & - & - & & - & & \\
\hline & Possibility if light shaft from ceiling & & & & & & - & & & & & - & & & - & \\
\hline & Limitation of light shaft from west & - & & & & & & - & & & & - & & - & & \\
\hline \multirow[t]{2}{*}{ wind } & $\begin{array}{c}\text { Natural ventilation based on thermo } \\
\text { syphon effect }\end{array}$ & & - & & & & & & & & & & & & $\bullet$ & \\
\hline & Creating stream & & & & - & - & & - & & & & & & & - & \\
\hline \multirow{12}{*}{$\begin{array}{l}\text { Application } \\
\text { of solar } \\
\text { elements } \\
\text { sealing }\end{array}$} & Absorption cooling system & - & & & & & & & & & & & & & & \\
\hline & EPDM hose & & & - & & & & & & & & & & & & \\
\hline & Hot water tanks & $\bullet$ & & - & & & & & & & & & & & & \\
\hline & $\begin{array}{c}\text { Protection technology against } \\
\text { lightening }\end{array}$ & & & & & & & & & & & & & & & \\
\hline & Electronic eye system & & & & & & & & & & & & & & & \\
\hline & B.M.S. system & & & & & & & & & & & & & & & \\
\hline & Solar panels & - & & & & & & & & & & & & & & - \\
\hline & Wind turbines & & & & & & & & & & & & & & & - \\
\hline & Louvre & & & & & & & & & & & & & & & \\
\hline & Hot water networks (stove) & - & & & & & & & & & & & & & & \\
\hline & Passive absorbed devices and tanks & & & & & & & & & & & & & & & \\
\hline & Solar lamps & & & - & & & & & & & & & & & & \\
\hline \multirow{7}{*}{$\begin{array}{l}\text { Applications } \\
\text { of plants }\end{array}$} & Walls and roof & - & - & & & & & & & & & - & & & - & \\
\hline & Double-glazed glasses windows & - & - & - & & & & & & & & - & & & & \\
\hline & Oxygen station & & & & & & & & & & & & & & & \\
\hline & Green house design & & & - & & & & & & & & & & & & \\
\hline & Expanding green house space in roof & & & & & & & & & & & & & & - & \\
\hline & Preserve existing trees & & & & - & & & & & & & & & & & \\
\hline & Used as a seasonable shade & & & & & & & & & & & & & & & \\
\hline site & $\begin{array}{c}\text { The relation of building and the } \\
\text { environment }\end{array}$ & & & & & - & & & - & & - & & - & & & \\
\hline \multirow{7}{*}{$\begin{array}{l}\text { Respecting } \\
\text { to users }\end{array}$} & Acoustic set & & - & - & & & & & & & & & & & & \\
\hline & Light set & & $\bullet$ & $\bullet$ & & & & & & & & & & & & \\
\hline & Thermal set & & - & - & & & & & & & & & & & & \\
\hline & Safety (lightening) & & - & & & & & & & & & & & & & \\
\hline & Flexible design & & - & & & & & & & & & & & & & \\
\hline & Good spatial relation & & & & & & & & & & - & & & & & \\
\hline & Suitable view & & & & & - & - & - & & & & & & & & \\
\hline
\end{tabular}


Table 7. Considering the stability factors in the samples (16-30) (source: author)

\begin{tabular}{|c|c|c|c|c|c|c|c|c|c|c|c|c|c|c|c|c|}
\hline \multicolumn{17}{|c|}{ ( } \\
\hline 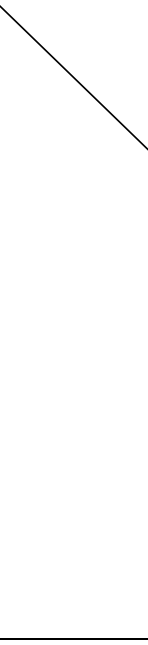 & Stability factors in design & 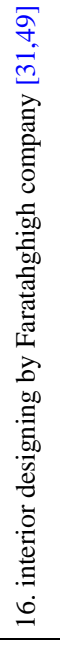 & 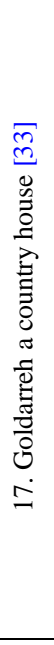 & 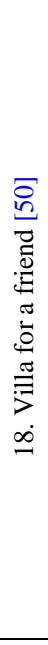 & 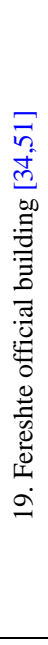 & 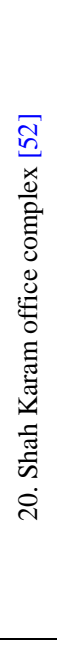 & 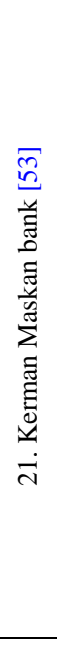 & 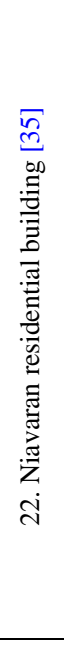 & 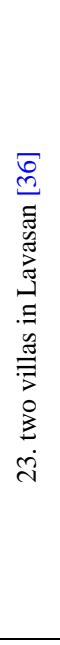 & 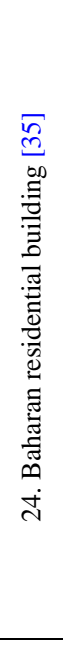 & 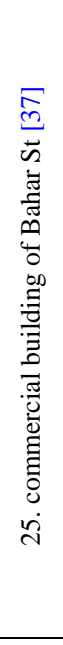 & 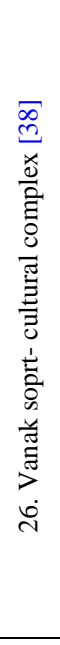 & 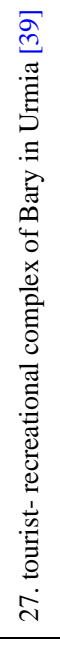 & 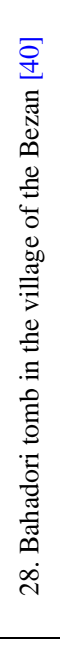 & 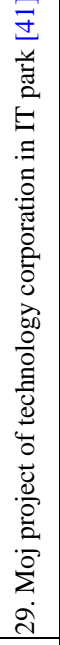 & 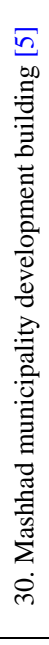 \\
\hline \multirow{12}{*}{$\begin{array}{c}\text { Form } \\
\text { (volume) }\end{array}$} & Two- shell design & & & & - & & - & & - & & & & & & & \\
\hline & The design on the pilot & & & & & & & & & & & & & & & \\
\hline & Creating a central courtyard places & & & & & & & - & & & & & & & & - \\
\hline & The impact of body surface area & & & & $\cdot$ & & & & & & & & & & & $\bullet$ \\
\hline & Plan form (compressed or stretched) & & & & $\bullet$ & & & & & & & & & & & \\
\hline & Spatial filter & & & & & & & & & & & & & & & \\
\hline & Windcatcher & & & & & & & & & & & & & & & \\
\hline & Zamharir (wind tunnel) & & & & & & & & & & & & & & & \\
\hline & Creating gaps in the body of building & & & & & & & & & & & & & & & \\
\hline & Green house design & & & & & & & & & & & & & & - & \\
\hline & Thermal storage & & & & & & & & & & & & & & $\bullet$ & \\
\hline & Volume canopy design & - & & & & & & & & & & & & - & $\bullet$ & \\
\hline \multirow{2}{*}{ orientation } & In the building & & & & - & & & & & & & & & & & \\
\hline & In fenestrations & & & & & & & & & & & & & & & \\
\hline \multirow{5}{*}{ materials } & Modern and new & & & & & - & & & & & & & & & & \\
\hline & local & & & - & & & & & & & & & & & & \\
\hline & $\begin{array}{l}\text { Stabile materials } \\
\end{array}$ & & & & & & & & & & & & & & & \\
\hline & Materials with high thermal capacity & & & & & & & & & & & & & & & \\
\hline & renewable & & & & & & & & & & & & & & & \\
\hline \multirow{3}{*}{ Light shaft } & Possibility of light shaft from windows & - & - & - & & - & - & & - & & - & & & - & - & - \\
\hline & Possibility if light shaft from ceiling & $\bullet$ & & & & & & & & - & $\bullet$ & & & & & \\
\hline & Limitation of light shaft from west & $\bullet$ & & & & & & & & & & & & - & & $\cdot$ \\
\hline \multirow[t]{2}{*}{ wind } & $\begin{array}{c}\text { Natural ventilation based on } \\
\text { thermosyphon effect }\end{array}$ & & & & & & $\bullet$ & & & & & & & & & \\
\hline & Creating stream & - & & & & & $\bullet$ & & - & & & & & & - & \\
\hline \multirow{12}{*}{$\begin{array}{c}\text { Applicatio } \\
\text { n of solar } \\
\text { elements } \\
\text { sealing }\end{array}$} & Absorption cooling system & & & & & & & & & & & & & & & \\
\hline & EPDM hose & & & & & & & & & & & & & & & \\
\hline & Hot water tanks & & & & & & & & & & & & & & & \\
\hline & Protection technology against lightening & & & & & - & & & & & & & & & & \\
\hline & $\begin{array}{l}\text { Electronic eye system } \\
\end{array}$ & & & & & $\bullet$ & & & & & & & & & & \\
\hline & B.M.S. system & & & & & & & & & & & & & & & \\
\hline & Solar panels & & & & & & & & & & & & & & & \\
\hline & Wind turbines & & & & & & & & & & & & & & & \\
\hline & Louvre & & & & & & & & & & & & & & & \\
\hline & Hot water networks (stove) & & & & & & & & & & & & & & & \\
\hline & Passive absorbed devices and tanks & & & & & & & & & & & & & & & \\
\hline & Solar lamps & & & & & & & & & & & & & & & \\
\hline \multirow{7}{*}{$\begin{array}{l}\text { Applicatio } \\
\text { ns of plants }\end{array}$} & Walls and roof & & & & & & & & & & & & & & - & - \\
\hline & Double-glazed glasses windows & & & & & & & & $\bullet$ & & & & & & $\bullet$ & $\bullet$ \\
\hline & Oxygen station & & & & & & & & & & & & & & & \\
\hline & Green house design & & & & & & & & & - & & & & & & \\
\hline & Expanding green house space in roof & & & & - & & & & & & & & & & & \\
\hline & Preserve existing trees & & & & $\bullet$ & & & - & & & & $\bullet$ & & & & \\
\hline & Used as a seasonable shade & & & & & & & & & & & & & & & \\
\hline site & $\begin{array}{c}\text { The relation of building and the } \\
\text { environment }\end{array}$ & & & & $\bullet$ & & & & & & & $\bullet$ & $\bullet$ & & & \\
\hline \multirow{7}{*}{$\begin{array}{l}\text { Respecting } \\
\text { to users }\end{array}$} & Acoustic set & & & & $\bullet$ & & & & - & & & & & & & \\
\hline & Light set & & & & & & & & $\bullet$ & & & & & & & \\
\hline & Thermal set & & & & & & & & - & & & & & & & \\
\hline & Safety (lightening) & & & & & & - & & & & & & & & & \\
\hline & Flexible design & & & & - & & & & - & & & & & & - & - \\
\hline & Good spatial relation & & & & $\bullet$ & & & & $\bullet$ & & & & & & & \\
\hline & Suitable view & & - & - & - & & & & & & & & - & & & \\
\hline
\end{tabular}


The results also indicated that $23 \%$ of buildings have considered a heating system among the most important tasks to reduce the need for fossil fuels by insulating the walls. The walls and roofs of these buildings are insulated and used double-glazed windows to decrease the heating loss. 23 percent usage of plants in buildings has resulted in addressing the issue of stability. The presence of oxygen stations to supply the oxygen in the atmosphere, green house design, and its development in ceiling is sometimes manifested through maintaining preserving the trees and the existing green space. In some buildings plant coverings are used as a shade according to the season.

In $23 \%$ of buildings , attention to the stability factor has taken effect by coordination of the building with the site and designers have tried to create coherence between the environment and the buildings. In $46 \%$ of the cases, respecting the users, stability objectives are achieved. While designing, this issue is considered in adjusting the acoustic, light and thermal situations, making the buildings safe via lightening, designing the flexibility of spaces to facilitate the function of building [25] and suitable designing of space relations, and considering suitable views.

Another important issue which was not observed in any of the projects is related to accounting for the value of the water and its recovery. In fact, water is one of the most important energy sources in building and its consumption is much higher than the standard level in our country. The main sources of water are rain and snow from which most of the water needed for the irrigation of plants and washing puposes is stored. Besides, there are some other miner consumptions which can be easily reduced. Sometimes cells could be installed on the floor to recover the waste water and thus use it for irrigation purposes and minor consumptions. these items depending on designing methods and thoughts can be overviewed and considered. Another approach to reduce energy consumption in buildings is to use geothermal sources. In fact, geothermal energy is obtained from layers under the ground. In this system hot water and a vapor are utilized to heat the building or to produce electricity. Geothermal is a renewable energy source as the rain water is replaced by the water and heating energy is produced on the ground. This approach can be viewed as an acceptable solution in the near-surface volcanic lands and areas with an easy access to warm water.

\section{Conclusions}

According to the case studies, In Iranian contemporary architecture, the quality of light absorbing of the building, have been considered as an important element in achieving the stability component. Therefore, designers have tried to use the best and maximum light to naturally bright the space. They have also formed the buildings according to the priority in different areas taking into consideration both the requirements as well as the climate. The third priority is observing the user laws including acoustic, thermal and light conditions that are regarded as thoughtful problems of users. In their attempts to propose the best possible designs, many designers have paid attention to factors such as ensuring the building security, creating the relationship between spaces, designing flexible buildings and finally designing suitable view. Among these samples, there were a number of projects that enjoyed a good wind flowing The wind does not limit to the cooling of the building. This component naturally ventilates the space based on thermosifon system that has been used in some buildings. As a result, the warm weather goes up pushing the cold weather downwards.

Therefore according to the observations made in present article, by observing small and primary points like building direction and light absorbing of the windows it is possible to Save energy in optimized way. Also by highlighting the strenght points and accurate study solutions used in similar climates in other parts of the world, it is possible to introduce new and fresh solutions in addition to those are beeing used currently. However, in order to make a major impact on energy consumption, these new approaches need to be carefully analyzed before being approved and finally implemented.

\section{References}

[1] Darsner, Simon, Principles of Stability, translated by Daneshvar Kakhaki, Mahmoud et al, Ferdowsi University of Mashhad, 2005.

[2] Kibert, Charles, sustainable construction: Green building design and delivery, Hoboken,N.J.: Jhon Wiley \& sons, third edition, 2012.

[3] aAhmadi, farhad, "sustainable architecture", Abadi, number 5 \& 6 of the new series.

[4] Azerbaijani, Mona - Mofidi, Seyed Majid, "The concept of stability architecture ", a set of the Third Conference about the optimization of fuel consumption in buildings, 2003.

[5] kamel nia, hamed- diba, darab- shayan, hamid, "Approaches of Contemporary Architecture of Iran", Journal of Architecture and Urbanism, 2006.

[6] Grout, Linda. David Wang, Architectural Research method, , John Wiley \& Sons, 2002, 341-374.

[7] Soflayi, Farzaneh, "Stability of climate elements in Iranian traditional architecture (hot and dry climate)", a set of the Third Conference about the optimization of fuel consumption in buildings, 2003.

[8] Khodabakhshi, Shohreh and Mofidi Seyed Majid, "Stability construction in relation to Iran's traditional architecture", Third International Conference of Energy, 2001.

[9] Singeri, Maryam, "Tabriz building design solutions based on stability architecture", First National Conference on Renewable Energy, Islamic Azad University, Takestan Branch, 2008.

[10] Nasr, Tahereh. (Suha), "Stability Architecture and the need for stability solutions in architecture", Civil International Journal, 74, 2010.

[11] Mofidi Shemirani, Seyed Majid - Akhtar Kavan, Mahdi, "Global indicators of stability development", First National Conference on Industry and Student and stability Development, 2007.

[12] Mellatparast, Mohammad, "Stability Architecture in the Iranian desert cities", Armanshahr, 3, 2009.

[13] Soleimani, Meysam , "Land and stability architecture" , Architecture and Cultural magazine, 33, 2008.

[14] Armaqhan, Maryam, Gorgi Mahlabany, Joseph, "The values of the Iranian vernacular architecture with stability architecture approach", Journal of Housing and Rural Environment, 2009.

[15] Maddahi, Seyed Mahdi, Seyed Mohammad Sagh Yazdannoost, "The considering principles and fundamentals of stability architecture and provide strategies to make it operation", Scientific-experience and research Monthly Magazine of road and construction architecture- installment and Urbanization, 2009.

[16] Seyed Almasi, M., "designed to promote climate solutions in order to reduce fuel consumption", a set of optimization of the Third Conference of fuel consumption in buildings, 2003.

[17] Jin Kim, Ji., Ryjdan, Bi., "An Introduction to Stability Design" , translated and Marve Farhoodi and Nazli Dbydyan in Iranian Architecture Quarterly - Ma, Number 14, 2009.

[18] Golabchi, Mahmood. Mazaherian, hamed, New architectural technologies, University of Tehran Press, 2009, 323. 
[19] Pirnia Mohammed Karim, Iranian Architecture of methodologies, compiling and gathering: Memarian GHolamhossein, Memar publishing, Third Edition, 2004, 30-31.

[20] Hajsaghti, Asqhar. Principles and applications of solar energy, Iran University of Science and Technology, 2001, 259.

[21] Mohammadzadeh, Moahmmad., "Considering of three experiments", Architect journal, 48, 28-34, 2008.

[22] Mahdavinejad, M., Doroodgar, A., Moradchelleh, A. (2012). The Impacts of Revivalist Trends on the Contemporary Architecture of Iran (1977-2011), Middle-East Journal of Scientific Research, 11 (2): 176-183.

[23] Mahdavinejad, M., Moradchelleh, A., Dehghani, S., \& Mirhosseini, S. M. (2013). The Adoption of Central Courtyard as a Traditional Archetype in Contemporary Architecture of Iran. World Applied Sciences Journal, 21(6), 802-811.

[24] Mahdavinejad, M., Ghaedi, A., Ghasempourabadi, M., Ghaedi, H.(2012). The Role of Vernacular Architecture in Design of Green Sidewalk, Case Study: Iran, Shushtar, Applied Mechanics and Materials, 2012, 220-223: 65-68.

[25] Mahdavinejad, M. Rezaei Ashtiani, S., Ebrahimi, M., Shamshirband, M. (2012). Proposing a Flexible Approach to Architectural Design as a Tool for Achievement Eco-Friendly Multi-Purpose Buildings, Advanced Materials Research, 622-623: 1856-1859.

[26] Review and Comment, "Some Iranian architect projects Padya and Part of Sahar Kish ", Architect journal, 38, 36-47, 2006.

[27] Project, "Ghiasi Home sweet dreams", Architect journal, 36, 64-69, 2006.

[28] Afshar Naderi, K., "works of Faramarz Sharifi", Architect journal, 33, 52-63, 2005.

[29] "Day clinic and rehabilitation center in Bam, Pirraz consulting engineers", Architect journal, 29, 58-63, 1994.

[30] "Residential apartment no.1 Mahallat", Architect journal, 89, 10 13, 2010.

[31] "Bagh Saba, Ritual Plays Center", Architect journal, 26, 50-57, 1994.

[32] Project introduction, "Reconstruction and interior design of office building of Fara Tahghigh Sepahan company", Architecture and building Journal, 14, 73-75, 2007.

[33] Introduction , "Countryside House in Goldarreh, F. Ataullahi, Mohammad Soltani Nasab", Architect journal, 18, 76-79, 2002.

[34] Project, "another experience in sustainable architecture Fereshteh Building F. Ahmadi and colleagues", Architect Magazine, 26, 4849, 2004.
[35] An Introduction of Iranian Modern Architecture, Cultural Association of Iranian architects' Engineers, Architect journal, 35, 14-23, 2005.

[36] Talaei Ismail, "Seven years of experience, two villas in Lavasan" Architect journal, 12, 40-51, 2001.

[37] Majidi, mohammad, "start with full hands", Architecture Magazine, 11, 48-53, 2001.

[38] Introduction, "Talae- Izadi joint project", Architecture Magazine 12, 51, 2001.

[39] Options Consulting Engineers, "Tourist Recreational Complex of Barry, Urmia, Options Consulting Engineers", Architect journal, 36, 76-79, 2006.

[40] Anbrany, Hamid, "Tomb of Bahador, the village of Tal Bzan, Masjed Soleiman", Architect journal, 18, 80-87, 2002.

[41] Gol Mohammadi, M.," Architecture Project of IT companies, park architectural plan of company members", Pardis Park Technology, 12, 2007.

[42] http://aliabkar.blogfa.com/post/4.[Accessed Apr. 25,2013].

[43] http://iran-eng.com/archive/index.php/t-193110.html.[Accessed Apr. 18, 2013].

[44] http://memarinews.com/Pages/News-3661.aspx.[Accessed Jun. 1, 2013].

[45] http://memarinews.com/Pages/News-4435.aspx.[Accessed May. 20, 2013].

[46] http://memarinews.com/Pages/News-3481.html.[Accessed Apr. 25, 2013].

[47] http://memarinews.com/Pages/News-3756.aspx.[Accessed Apr. 25, 2013].

[48] http://nama61j.blogfa.com/post-139.aspx. [Accessed Jun. 3,2013]

[49] http://memarinews.com/Pages/News-3758.aspx.[Accessed Apr. 28, 2013].

[50] http://memarinews.com/Pages/News-4036.aspx.[Accessed Apr. 25, 2013].

[51] http://memarinews.com/Pages/News-4738.aspx.[Accessed May. 6, 2013].

[52] http://memarinews.com/Pages/News-4035.aspx.[Accessed Apr. 12, 2013].

[53] http://memarinews.com/Pages/News-4434.aspx.[Accessed Jun. 3, 2013].

[54] http://eng.mashhad.ir/services/portal_content/16129.[Accessed Apr. 25, 2013]. 